\title{
Life cycle assessment of combination of anaerobic digestion and pyrolysis: focusing on different options for biogas use
}

\author{
Ali Mohammadi, G. Venkatesh, Maria Sandberg, Samieh Eskandari, and Karin Granström \\ Department of Engineering and Chemical Sciences, Karlstad University, Karlstad, Sweden
}

Correspondence: Ali Mohammadi (mohammadia2011@gmail.com, ali.mohammadi@kau.se)

Received: 31 May 2019 - Accepted: 7 August 2019 - Published: 29 August 2019

\begin{abstract}
The combination of anaerobic digestion and pyrolysis technologies could be a novel energy-biochar production system to maximize energy and nutrient recovery from pulp and paper mill sludge. Herein, the life-cycle energy production and emissions reduction of sludge treatment from a typical pulp and paper mill were investigated, in which alternative uses of biogas for industrial or household application, in different regions of the world, were assessed. The three scenarios considered for different end-uses of biogas are: (A) biogas for vehicle fuel in the transportation sector in Sweden, (B) biogas for heat and electricity in the power sector in Brazil, and (C) biogas for cooking in households in China. The results of Environmental Life-Cycle Assessment (E-LCA) show that for all these three scenarios, the use of biogas and pyrolysis gas contributes most to emissions mitigation, while the dewatering and drying processes carried out on the sludge, contribute the most to the environmental emissions. Addition of biochar to the soil, contributes significantly to a reduction in global warming by sequestering carbon in the soil. Compared to scenarios B and C, Scenario $\mathrm{A}$, in which biogas substitutes gasoline in transportation, and heat from combusted pyrolysis gases is used for district heating in Sweden, demonstrates the highest environmental performance for all the evaluated impact categories.
\end{abstract}

\section{Introduction}

Wastewater - municipal, industrial and agricultural - holds within itself a wide variety of organic and inorganic constituents, which can be looked upon as resources. The resources from wastewater can be recovered and recirculated to the anthroposphere, in a circular economy, which many countries in the world are striving to move towards. The mo- tivations behind attempting to close the loop are manifold - economic and environmental, geopolitical and social. The primary driving factors, obviously, are not the same in all regions of the world. Research into the recovery of different constituents has been going on, and will continue to attract interest, support, investments and attention in the future. Recovery and recycling of resources from wastewater will aid in the conservation of virgin resources - both biotic and abiotic, and also of the quality of sinks into which the anthroposphere disposes its wastes (Venkatesh, 2018). Consequently, environmental impacts associated with the production of goods which are replaced thereby, are avoided.

Pulp and paper mills discharge significant amounts of sludge, and the wastewater sludge is an industrial waste that needs to be handled responsibly to control pollution. There are several methods in which sludge can be handled, to recover energy and nutrients. Biogas derived from wastewater sludge through anaerobic digestion (AD), has the potential to replace fossil fuels, in the supply of electricity, heat and transportation fuel (Chen and Chen, 2013; Pöschl et al., 2010). Pyrolyzing and hydrothermal carbonization of the sludge can yield biochar as a useful nutrient-rich byproduct for soil application while also supplying renewable heat energy by capturing produced gases (Mohammadi et al., 2019a; Eskandari et al., 2019). Integrating both these sludgehandling approaches serves to diversify the range of byproducts and can improve energy recovery from sludge (Cao and Pawłowski, 2012). What is relevant for municipal sludge, is also true for paper and pulp mill sludges. Changes and interventions which are incorporated in a circular bio-economy need to be tested for environmental sustainability. Environmental life-cycle assessment (E-LCA) serves as a powerful tool in the sustainability analysis toolkit and enables analysts to uncover both benefits (impact reductions) and any benefit- 
offsetting factors (impacts caused by the processes comprising these interventions) (Mohammadi et al., 2017a).

E-LCA has been previously applied to AD of wastewater sludge by researchers (Chen and Chen, 2013; Suh and Rousseaux, 2002) and the results show that the AD reduced significantly the environmental costs of sludge disposal compared with the traditional practice of landfill. However, literature review shows that the environmental performance of using paper mill sludge in the integration of anaerobic digestion and pyrolysis technologies (Li and Feng, 2018) or alternative uses of biogas (Colzi Lopes et al., 2018), particularly in different regions of the world, has not attracted much attention.

The authors have hitherto demonstrated that using pulp and paper mill sludge in pyrolysis and $\mathrm{AD}$ plants significantly reduces the environmental footprints of sludgehandling relative to landfilling and incineration (Mohammadi et al., 2019a, b, c). Using sludge in AD plants results in the production of biogas and this can be used for a variety of end-uses, supplanting different alternatives in different parts of the world. E-LCA has been applied in this particular paper to investigate the environmental footprints of using biogas as a transport fuel in Sweden (the most common application in this country), for co-generation of heat and electricity in Brazil and as a cooking fuel in households in China.

\section{Materials and Methods}

\subsection{Goal and scope definition}

The goal of this E-LCA is to determine environmental performance of three anaerobic digestion (AD)-pyrolysis systems using pulp and paper wastewater sludge as a feedstock with different applications of biogas and pyrolysis gases. The enduses of biogas which have been selected in this article, are globally the most-common ones for the utilization of biogas.

In the application of E-LCA to waste management, various functional units (FUs) can be chosen. Nevertheless, the mass-based functional unit is most common in LCA studies of waste treatment systems (Suh and Rousseaux, 2002; Mohammadi et al., 2016b). Therefore, in this study, $1 \mathrm{t}$ (tonne) of dry matter sludge in each biogas-biochar scenario has been considered as the FU. The details of sludge composition are shown in the Supplement, Table S1.

The system boundary included all processes from sludge gathering to the end-use of biogas and by-products. In all these scenarios, sludge is converted into biogas, heat energy and biochar. To investigate the environmental costs and benefits of co-products, the system expansion approach was adopted in this study.

\subsubsection{Scenario A: biogas as a fuel in the Swedish transport sector}

In this scenario, sludge is collected from the mill, dewatered and delivered to the $\mathrm{AD}$ plant, in which biogas is generated (Fig. 1). The biogas, a mixture of carbon dioxide $\left(\mathrm{CO}_{2}\right)$, methane $\left(\mathrm{CH}_{4}\right)$, and other constituents is then led to an upgrading unit where $\mathrm{CO}_{2}$ and other constituents are removed. The upgraded biogas, a methane-rich output, is used for vehicle fuel in the transportation sector in Sweden to displace diesel. In addition to biogas, the AD produces digestate as a co-product where the non-mineralised organics are accommodated. The digested sludge is dewatered to $65 \% \mathrm{MC}$, and then dried in an external dryer to $15 \%$ moisture content (MC), before delivery to a large-scale pyrolysis facility.

The pyrolysis gases are captured and combusted at high temperatures to minimize the generation of incomplete combustion products. The heat from combusting these gases is recovered on-site and used to fuel the pyrolysis process and dry digestate prior to the next pyrolysis cycle, and also for space heating in Swedish households; this has the potential to lessen the load on the district heating plants in the country. The biochar produced from the digested sludge was assumed to be incorporated into forest soils in Sweden.

\subsubsection{Scenario B: biogas for co-generation of heat and electricity in Brazil}

This scenario uses paper mill sludge to generate biogas, heat energy and biochar. The dewatered sludge is anaerobically digested for biogas. The biogas is then delivered to combined heat and power (CHP) units for heat and electricity production. Decentralized power generation with CHP plants and feed-in of excess capacity to the national grid is a common biogas utilization pathway in Brazil (Coimbra-Araújo et al., 2014). The co-product of digestate is dewatered, and then dried before being pyrolyzed by the large-scale pyrolysis unit. Residual heat from pyrolysis (as discussed in the previous sub-section) and all heat from CHP units is employed to dry grain before storage. The biochar from carbonization process is transported to forest sites, to be subsequently mixed with the soil, as an amendment.

\subsubsection{Scenario C: biogas as a cooking fuel in households in China}

Biogas use for household activities is prevalent among many families in China, who rarely have access to other renewable energy sources (Chen et al., 2010). In Scenario C, biogas from anaerobic digestion of paper mill sludge is considered as a cooking fuel in Chinese households. Dewatered and dried digestate is pyrolyzed for biochar as a soil conditioner. Residual heat from the combustion of pyrolysis gas is used for cooking or drying purposes substituting natural gas, and the biochar is applied into forestlands. 


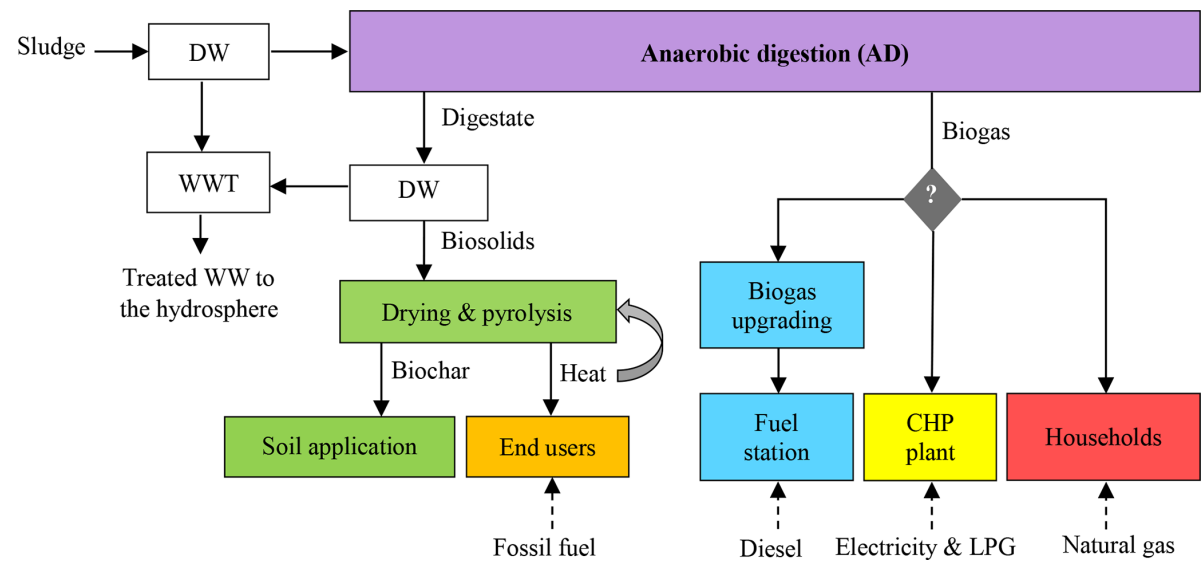

Figure 1. Life cycle diagram for three different uses of biogas, including pyrolysis for digestate management. The DW, WWT, LPG and CHP represent the dewatering, wastewater treatment, liquefied petroleum gas and combined heat and power respectively. The biochar is assumed to be incorporated into unfertilized forest soils.

\subsection{Inventory analysis}

The life cycle inventory was analysed coupling relevant published data, experimental results for the AD process, and the ecoinvent 3.1 (Inventories, 2014) and ELCD databases (European-Commission, 2014) under Swedish, Brazilian and Chinese conditions for scenarios A, B and C respectively.

Data concerning the AD treatment of pulp and paper mill sludge were directly obtained via biogas experiments conducted at Karlstad University, Sweden (Granström et al., 2014; Granström, 2014), to which all the authors belong. In this experiment, about $50 \%$ of the volatile organic matter in the sludge is converted to biogas during the digestion process. The quantity of biomethane generated was measured and this was used to determine the masses of the constituents of biogas, assuming a composition of $63 \%$ methane $\left(\mathrm{CH}_{4}\right), 36 \%$ carbon dioxide $\left(\mathrm{CO}_{2}\right)$ and $1 \%$ hydrogen sulphide $\left(\mathrm{H}_{2} \mathrm{~S}\right)$ (Persson et al., 2006). The dry weight percentage of solid residues from this process is $5 \%$. About $13 \mathrm{kWh}$ of electricity per $\mathrm{t}$ of dry sludge is consumed for agitation and pumping, and $59 \mathrm{kWh}$ of electricity per $\mathrm{t}$ of dry sludge is required for dewatering process to decrease the MC of digestate material from $95 \%$ to $80 \%$, and $5 \mathrm{kWh}$ extra electricity for dewatering to $65 \% \mathrm{MC}$. For using biogas as a fuel for vehicles, it needs to be upgraded in order to remove $\mathrm{CO}_{2}$ and other impurities and to make it richer in methane. Water scrubbing, a common method for biogas upgrading, was considered in this study. Data for electricity use in the water scrubbing process was sourced from Starr et al. (2012).

The conversion efficiency in CHP units for heat and electricity was considered $40 \%$ and $48 \%$, respectively based on for large-scale biogas plants (Pöschl et al., 2010). The inplant electricity consumption in CHP is $4.5 \%$ of the generated output. A $10 \%$ heat loss in the district heating network was taken into account based on a transmission distance of $5 \mathrm{~km}$. The use of heat from CHP and pyrolysis gases was as- sumed to avoid the use of liquefied petroleum gas (LPG) in Scenario B. In this study, the typical biogas application for cooking (biogas stove) was considered (Chen et al., 2010), which is used in place of natural gas cooking for Chinese families. The calculations we used to account the emissions from biogas end-use (transport, CHP and heat) can be found in the sources (Börjesson and Berglund, 2006; Pöschl et al., 2010).

The behaviour of heavy metals in the feedstock during $\mathrm{AD}$, incineration and carbonization is difficult to model owing to the high degree of uncertainty associated with it. Several studies have shown that a significant percentage of the heavy metals in the sludge remain in the solid residue during the AD process (Al Seadi and Lukerhurst, 2012) and pyrolysis (Lu et al., 2016). In the current assessment, the heavy metal concentrations in the raw sludge and digested sludge were used from the biogas experiments where these data were measured (Granström et al., 2014). Except mercury $(\mathrm{Hg})$ which is relatively more atmophilic, all the heavy metals in digested sludge were assumed to be completely partitioned to the biochar. The mobility of heavy metals in the soil due to biochar incorporation was estimated from Devi and Saroha (2014). In this source, the fates of the heavy metals in biochar produced from paper mill sludge have been examined.

In this study, due to lack of data, the biochar produced from digested sludge was assumed to have the same carbon as biochar from paper mill sludge. Sludge biochar was considered to have a carbon content of $50 \%$ (Van Zwieten et al., 2010), of which $80 \%$ is considered to remain in the soil after the time horizon of 100 years (Lehmann and Joseph, 2015; Sparrevik et al., 2013).

Addition of biochar to forest soils can influence the soil greenhouse gas (GHG) emissions (Li et al., 2018). However, it has been seen that the biochar effect on the soil emissions varies from a significant reduction in dinitrogen monoxide 
Table 1. Inventory for AD-pyrolysis combination systems (expressed per $1 \mathrm{t}$ of dry sludge).

\begin{tabular}{|c|c|c|c|}
\hline & Unit & Amount & Comments/source \\
\hline \multicolumn{4}{|l|}{ Inputs } \\
\hline Sludge & $\mathrm{kg}$ & 1000 & \\
\hline Electricity & $\mathrm{kWh}$ & 823.5 & \\
\hline Dewatering biosludge & $\mathrm{kWh}$ & 40 & To $92 \% \mathrm{MC}$ \\
\hline Anaerobic digestion (AD) & $\mathrm{kWh}$ & 13 & \\
\hline Biogas upgrading & $\mathrm{kWh}$ & 44.5 & Only in Scenario A \\
\hline Dewatering digestate & $\mathrm{kWh}$ & 64 & To $65 \% \mathrm{MC}$ \\
\hline Sludge drying & $\mathrm{kWh}$ & 653.6 & To $15 \% \mathrm{MC}$ \\
\hline Pyrolysis & $\mathrm{kWh}$ & 8.7 & \\
\hline Diesel fuel & 1 & 0.1 & For the start-up \\
\hline Chemicals & & & $\begin{array}{l}\text { For dewatering, flue gas and wastewater (WW) treatments (Suh and } \\
\text { Rousseaux, 2002; Heimersson et al., 2014) }\end{array}$ \\
\hline Polymer & $\mathrm{kg}$ & 9 & For dewatering process \\
\hline Calcium chloride $\left(\mathrm{CaCl}_{2}\right)$ & $\mathrm{kg}$ & 0.36 & Heavy metal removal in wet scrubber production of gypsum \\
\hline Sodium persulfate $\left(\mathrm{Na}_{2} \mathrm{~S}_{2} \mathrm{O}_{8}\right)$ & $\mathrm{kg}$ & 0.35 & To improve precipitation of heavy metals \\
\hline Sodium hydroxide $(\mathrm{NaOH})$ & $\mathrm{kg}$ & 18.6 & Neutralization agent in alkaline scrubbing \\
\hline Ammonia $\left(\mathrm{NH}_{3}\right)$ & $\mathrm{kg}$ & 0.89 & Reduction of $\mathrm{NO}_{x}$ to $\mathrm{N}_{2}$ \\
\hline Hydrochloric acid $(\mathrm{HCl})$ & $\mathrm{kg}$ & 1.1 & For $\mathrm{pH}$ control in WW from the wet scrubber \\
\hline Sulphuric acid $\left(\mathrm{H}_{2} \mathrm{SO}_{4}\right)$ & $\mathrm{kg}$ & 0.66 & For $\mathrm{pH}$ control in WW from the wet scrubber \\
\hline Sodium chloride $(\mathrm{NaCl})$ & $\mathrm{kg}$ & 0.32 & Salt for softening \\
\hline \multicolumn{4}{|l|}{ Outputs } \\
\hline $\mathrm{CH}_{4}$ & $\mathrm{~m}^{3}(\mathrm{GJ})$ & $137.9(5.3)$ & Measured from the experiment (Granström et al., 2014; Granström, 2014) \\
\hline Heat & GJ & 5.8 & For end users and pyrolysis process* \\
\hline Biochar & $\mathrm{kg}$ & 172 & $1 \%$ and $3 \%$ losses during transport and handling \\
\hline \multicolumn{4}{|l|}{ Emissions from $\mathrm{AD}$ and pyrolysis } \\
\hline $\mathrm{H}_{2} \mathrm{~S}$ & $\mathrm{~kg}$ & 1.6 & \\
\hline $\mathrm{CH}_{4}$ & g & 51.7 & Estimated from BigChar (2015) \\
\hline $\mathrm{NO}_{x}$ & $\mathrm{~g}$ & 68.3 & \\
\hline $\mathrm{SO}_{x}$ & $\mathrm{~g}$ & 19.2 & \\
\hline $\mathrm{N}_{2} \mathrm{O}$ & $\mathrm{g}$ & 0.05 & \\
\hline $\mathrm{PM}_{10}$ & g & 3.4 & \\
\hline \multicolumn{4}{|c|}{ Emissions to soil from land application of biochar } \\
\hline Cadmium $(\mathrm{Cd})$ & $\mathrm{g}$ & 0.17 & Estimated based on Devi and Saroha (2014) \\
\hline Chromium $(\mathrm{Cr})$ & $\mathrm{g}$ & 6.24 & \\
\hline Copper (CU) & $\mathrm{g}$ & 1.6 & \\
\hline Nickel (Ni) & $\mathrm{g}$ & 1.9 & \\
\hline Lead $(\mathrm{Pb})$ & $\mathrm{g}$ & 0.21 & \\
\hline Zinc (Zn) & $\mathrm{g}$ & 7.31 & \\
\hline \multicolumn{4}{|c|}{ Emissions to water from wastewater treatment } \\
\hline Cadmium (Cd) & $\mathrm{g}$ & 0.1 & \\
\hline Lead $(\mathrm{Pb})$ & $\mathrm{g}$ & 5.8 & \\
\hline Zinc (Zn) & $\mathrm{g}$ & 6.4 & \\
\hline \multicolumn{4}{|l|}{ Other assumptions } \\
\hline Conversion efficiency in CHP & $\%$ & $40-48$ & Electricity-heat \\
\hline Sludge biochar yield & $\%$ & 35 & \\
\hline Transport distance & $\mathrm{km}$ & 100 & From pyrolysis unit to forest site \\
\hline Carbon content of biochar & $\%$ & 50 & Van Zwieten et al. (2010) \\
\hline Stable carbon content of biochar & $\%$ & 80 & Lehmann and Joseph (2015) \\
\hline Efficiency for transferring heat & $\%$ & 90 & BigChar (2015) \\
\hline
\end{tabular}

* The total energy requirement of pyrolysis process was estimated to be $1060 \mathrm{MJ} \mathrm{t}^{-1}$ dry sludge (Li and Feng, 2018). 
Table 2. End-use emissions of biogas in different scenarios (g per 1 tonne of dry sludge).

\begin{tabular}{lrrr}
\hline Emissions* & Scenario A & Scenario B & Scenario C \\
\hline $\mathrm{CO}$ & 956.7 & 89.0 & 40.3 \\
$\mathrm{NO}_{x}$ & 704.9 & 267.0 & 50.4 \\
$\mathrm{SO}_{2}$ & 6.0 & 13.4 & 15.1 \\
$\mathrm{HC}$ & 463.2 & 13.4 & 15.1 \\
$\mathrm{CH}_{4}$ & 453.2 & 17.8 & 20.2 \\
Particles $\left(\mathrm{PM}_{10}\right)$ & 45.3 & 8.9 & 10.6 \\
\hline
\end{tabular}

* Estimated based on Börjesson and Berglund (2006).

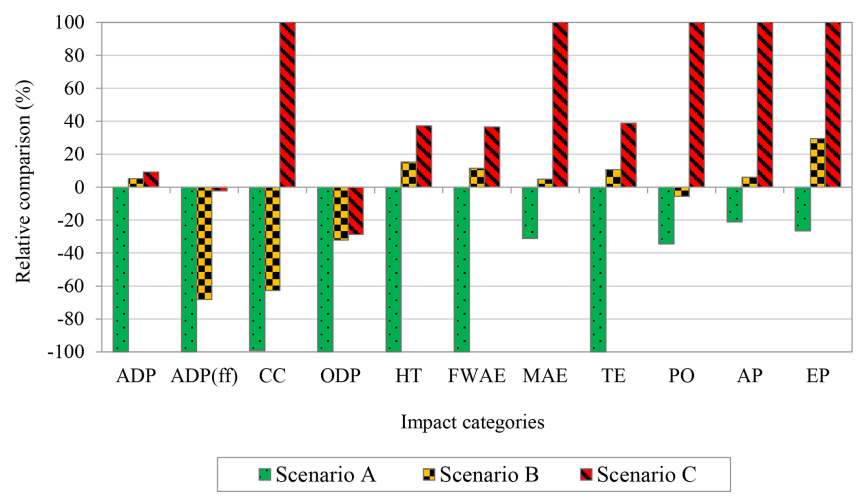

Figure 2. Environmental impact of AD-pyrolysis scenarios: relative comparison among the three alternative biogas uses.

$\left(\mathrm{N}_{2} \mathrm{O}\right.$ ) emissions in fertilized forests, to more complex (negative, positive, or negligible) changes in the emissions of $\mathrm{CH}_{4}$ and $\mathrm{CO}_{2}$. Most of productive forests globally are not fertilized (Jacobson and Pettersson, 2010), so in this study, biochar was reasonably assumed to be used in unfertilized forest sites.

Biochar was assumed to be spread on the soil using a mechanical spreader. Due to lack of enough data on the effects of the biochar on tree growth over time, the carbon stock response in trees was not included in this study. Published data about emissions from the site were used to model pyrolysis (BigChar, 2015). The environmental impacts associated with the setting-up and maintenance of the infrastructure were not included on the premise that these are amortized over a reasonably long useful lifetime. Inputs and assumptions related to life cycle inventory of all the three scenarios are summarized in Table 1, and emissions from end-use of biogas are presented in Table 2.

\subsection{Impact assessment}

A life cycle impact assessment (LCIA) was performed using SimaPro 8.0.4 software (PRè Consultants, 2014), and mid-point impact method CML-IA developed by the Centre of Environmental Science (CML-IA) of Leiden University in The Netherlands was chosen to assess the environmen- tal impact. The datasets used for all the three LCA scenarios are presented in Table S2. The following impact potentials were calculated according to the selected method: abiotic depletion (ADP), abiotic depletion (fossil fuel) $\left(\mathrm{ADP}_{(\mathrm{ff})}\right)$, climate change (CC), ozone layer depletion (ODP), acidification (AP), eutrophication (EP), and photochemical oxidation (PO), terrestrial ecotoxicity (TE), human toxicity (HT), fresh water aquatic ecotox. (FWAE), marine aquatic ecotoxicity (MAE).

\section{Results and discussion}

\subsection{Environmental performance of three scenarios}

The E-LCA results of the three biogas pathways are presented in Table 3. For Scenario A, where biogas is used for the transportation sector in Sweden, abatement of the emissions was greater than the emissions per se, resulting in a negative value for all the environmental impacts. For Scenario $\mathrm{B}$, except $\mathrm{ADP}_{(\mathrm{ff})}, \mathrm{CC}, \mathrm{ODP}$, and $\mathrm{PO}$ which are negative, the other impacts have positive values, and for Scenario $\mathrm{C}$, only $\mathrm{ADP}_{(\mathrm{ff})}$ and ODP impacts showed emissions mitigation.

Figure 2 demonstrates the comparison between the three pathways: biogas for the transportation (Scenario A), biogas for heat and electricity (Scenario B), and biogas for cooking (Scenario C). For all the evaluated impact categories, the Scenario A shows better environmental performance compared to other scenarios; differences are large, varying from $32 \%$ for $\mathrm{ADP}_{(\mathrm{ff})}$ in Scenario $\mathrm{B}$ to $574 \%$ for AP in Scenario C. Overall, the environmental benefit of the three pathways would follow the order: Scenario $\mathrm{C}<$ Scenario $\mathrm{B}<$ Scenario A based on the assessed impact categories. Given that, the environmental performance of production and application of biogas from $\mathrm{AD}$ of wastewater sludge is influenced by the biogas usage in different regions of the world. The observed differences between the biogas scenarios are mainly due to various application of biogas and pyrolysis gases as well as the sources of electricity production in Sweden, Brazil and China. Therefore, the displaced fuel due to use of biogas and pyrolysis gases as well as the amount of required electricity play a big role in differentiating the LCA results of the selected countries.

Our results for Scenario $\mathrm{C}$ are in agreement with $\mathrm{Li}$ and Feng (2018) where using sludge in the AD-pyrolysis integration was compared with $\mathrm{AD}$ and pyrolysis processes separately in China. In this work, they reported the positive amounts (emissions larger than abatement) for most of evaluated impact categories including CC, HT and EP. However, in their study biogas was supplied to CHP system and the heat generated from the CHP was first used for the AD and the residual heat is used to dry the feedstock while in the present study biogas is supplement to households for cooking and an 
Table 3. Values for impact categories.

\begin{tabular}{|c|c|c|c|c|c|}
\hline Impact category & Abbreviation & Units & Scenario A & Scenario B & Scenario C \\
\hline Abiotic depletion & ADP & kg Sb eq. & $-2.26 \times 10^{-6}$ & $1.15 \times 10^{-7}$ & $2.08 \times 10^{-7}$ \\
\hline Abiotic depletion(fossil fuels) & $\mathrm{ADP}_{(\mathrm{ff})}$ & MJ & -8.45 & -5.76 & -0.195 \\
\hline Climate change & $\mathrm{CC}$ & $\mathrm{kg} \mathrm{CO}_{2}$ eq. & -0.428 & -0.27 & 0.431 \\
\hline Ozone layer depletion & ODP & kg CFC-11 eq. & $-8.77 \times 10^{-8}$ & $-2.82 \times 10^{-8}$ & $-2.52 \times 10^{-8}$ \\
\hline Human toxicity & HT & kg 1,4-DB eq. & -0.111 & 0.0168 & 0.0412 \\
\hline Fresh water ecotox. & FWE & kg 1,4-DB eq. & -0.106 & 0.0122 & 0.0388 \\
\hline Marine aquatic ecotoxicity & MAE & kg 1,4-DB eq. & -238 & 36.6 & 765 \\
\hline Terrestrial ecotoxicity & $\mathrm{TE}$ & kg 1,4-DB eq. & -0.00144 & 0.000152 & 0.00056 \\
\hline Photochemical oxidation & $\mathrm{PO}$ & $\mathrm{kg} \mathrm{C}_{2} \mathrm{H}_{4}$ eq. & $-5.9 \times 10^{-5}$ & $-9.6 \times 10^{-6}$ & 0.000171 \\
\hline Acidification & $\mathrm{AP}$ & $\mathrm{kg} \mathrm{SO}_{2}$ eq. & -0.00117 & 0.000332 & 0.00557 \\
\hline Eutrophication & $\mathrm{EP}$ & $\mathrm{kg} \mathrm{SO}_{2}$ eq. & -0.000214 & 0.000237 & 0.000805 \\
\hline
\end{tabular}

extra dryer was assumed for thermal drying of the digested sludge (the same assumption for all the three scenarios).

In another study in China (Chen and Chen, 2013), different biogas-sludge use alternatives (for biogas: cooking, CHP and heat; for digestate: landfill, incineration and nutrient processing) were compared in China from the perspective of environmental sustainability. The authors of the paper referred to, concluded that the joint application of household biogas use and sludge nutrient processing for top soil spreading can represent an optimal trade-off for domestic wastewater treatment sludge.

\subsection{Contribution analysis}

A contribution analysis was performed with reference to $1 \mathrm{t}$ dry sludge to quantify the relative influences of the life-cycle stages contributing to the impact categories in each of the three scenarios (Fig. 3). Based on this analysis, the avoided use of district heating fuels due to the use of heat from pyrolysis gases was the dominant process in most of environmental impacts in Scenario A (Fig. 3a). The contribution of this process ranged from $33 \%$ (CC mitigation) to $97 \%$ (TE reduction). Biogas application for transport had varying contributions to the impacts mostly to $\mathrm{ADP}_{(\mathrm{ff})}$ with a negative contribution of $54 \%$ in this scenario.

In Scenario B, the major processes are the use of biogas in CHP units, pyrolysis gas application, drying digested sludge, addition of biochar into soil and dewatering (Fig. 3b). Approximately $46 \%$ of $\mathrm{ADP}_{(\mathrm{ff})}$ and $48 \%$ of ODP can be attributed to LPG displaced due to the utilization of pyrolysis gases for drying grain. The eutrophication impact originating from dewatering, biogas application and sludge drying processes was $28 \%, 15 \%$ and $37 \%$ respectively. The AP, TE and HT impacts are primarily caused by sludge drying because of a large amount of electricity is required for this part. Flue gas treatment is responsible for almost $13 \%$ of MAE and AP impacts. This is largely associated with using sodium hydroxide in wet flue gas cleaning system. The contribution of biogas application in Scenario B to the impact reductions ranged from $14 \%$ (AP) to $41 \%$ (TE).

In Scenario $C$, dewatering and drying sludge were the critical processes owing to their strong reliance on electricity use; and also the fact that the Chinese electricity mix is dominated by coal (Ang and Su, 2016). The emissions associated with drying digested sludge had a major contribution to all the impact categories, except ODP, varying from $33 \%$ (ADP) to $78 \%$ (TE) (Fig. 3c). The contribution of the dewatering process was the largest to ADP (37\%) and the second largest to EP $(22 \%)$. Other LCA studies on sludge treatment (Li and Feng, 2018; Hong et al., 2009) reported similar results where the dewatering and drying processes were the primary contributors to different environmental impacts. The use of biogas in households played a key role in $\mathrm{ADP}_{(\mathrm{ff})}$ and ODP with negative contributions of $26 \%$ and $41 \%$ respectively. Heat from pyrolysis gases substituted fossil-based energy sources and contributed to reductions of ODP, $\mathrm{ADP}_{(\mathrm{ff})}$ and HT by $38 \%, 24 \%$ and $21 \%$ respectively.

The soil application of biochar was the largest contributor to the abatement of GHG emissions in Scenario A and Scenario $\mathrm{B}$, accounting for $40 \%$ and $36 \%$ respectively, and the second major contributor to the climate change mitigation in Scenario C $(20 \%)$. The stabilized carbon in biochar led to the negative contribution of the process of biochar land application. This result is in keeping with the other findings of the LCA studies (Mohammadi et al., 2016a; Brassard et al., 2018; Ji et al., 2018) which have found the carbon stored in biochar contributed to between $20 \%$ and $50 \%$ of the abatement of carbon footprint.

\subsection{Development of AD-pyrolysis systems}

Since diesel and natural gas are commonly used in the transport and power sectors in the world, substituting them with biogas will play a significant role in the decarbonisation of many economies in the world. This is why the production of biogas through the anaerobic digestion process was considered as an alternative method for handling pulp and paper 

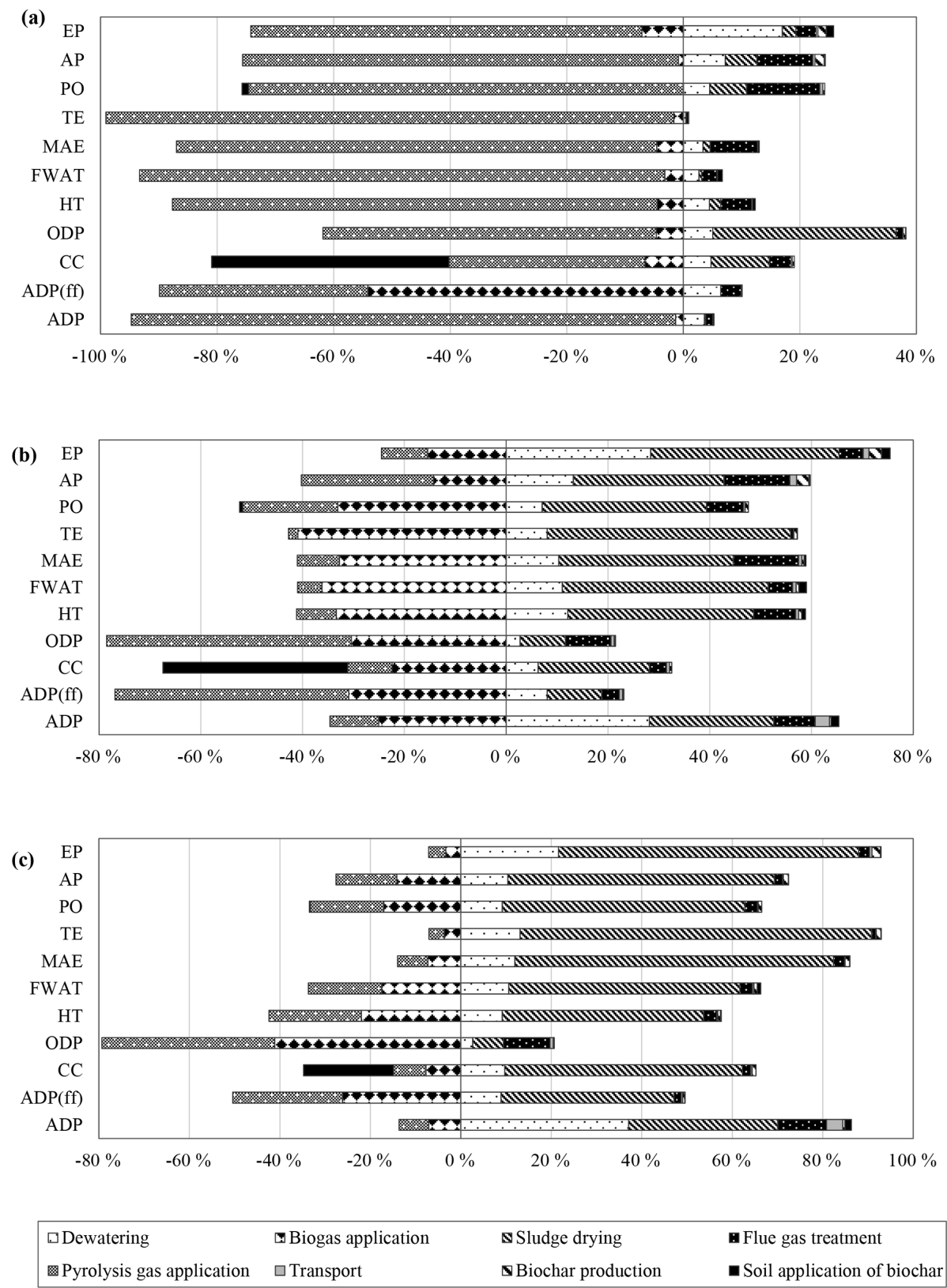

Figure 3. Contribution of life cycle stages to total environmental impacts of the different pathways. (a) System A: biogas for the transportation sector in Sweden, (b) System B: biogas for CHP plants in Brazil, and (c) System C: biogas for cooking in China.

mill sludge. In this study, it was assumed that all the biogas produced is captured for external use, while the energy needs of the digestion, dewatering and drying processes are fulfilled by other supply sources. Our results demonstrated that to improve the environmental performance of the system further, particularly in regions like China, improvements in sludge dewatering and drying are needed for the pyrolysis process. In other words, the alternative wastewater treatment system can reduce the amount of biogas in the end-use such as CHP units, making the plant totally self-sufficient when it comes to its energy requirements (Colzi Lopes et al., 2018).
Having pyrolysis process in the system, integrated with $\mathrm{AD}$, converts the digested sludge into biochar as a soil amendment and it could be an optimum solution for sludge management. The disposal of wastewater sludge is a global challenge, and is becoming costlier and more restricted due to environmental regulations, owing to the high concentrations of heavy metals in them. Pyrolysis is a promising sludge treatment method for heavy metals immobilization (Devi and Saroha, 2014).

Forest sustainability and productivity declines due to nutrient removal in stands harvested repeatedly and nutrient 
leaching from the soils (Vadeboncoeur et al., 2014). Therefore, to keep forest ecosystems sustainable, nutrient pools, e.g. $\mathrm{N}, \mathrm{P}, \mathrm{K}, \mathrm{Mg}$ and $\mathrm{Ca}$, should be regularly replenished. Currently, recycling of granulated wood ash to the forest soils, is a common practice in some countries like Sweden to improve the nutrient supply and to restore $\mathrm{pH}$ in acidified soils, due to its liming effect. However, its effects on soil nutrients is only short-lived due to the high solubility of nutrients such as $\mathrm{K}$ and $\mathrm{Na}$ oxides which leach quickly (Ulery et al., 1993). Literatures suggest that the production of biochar from sludge for soil application is an efficient method to recycle nutrients and increase soil fertility (Silva et al., 2017; Paz-Ferreiro et al., 2012). Biochar addition into soils can also improve soil physical and biological properties, raise soil organic carbon pools (Li et al., 2018), water holding capacity and consequently improve plant production. Moreover, it reduces soil acidification, due to its alkaline nature, and soil GHG emissions (Huang et al., 2013; Mohammadi et al., 2016a) while mitigating climate change impacts by sequestering carbon in soils over a long period of time.

However, prior to widespread adoption of these systems, it is important to investigate other aspects such as the social, economic, development status and environmental constraints as well. For instance, costs of capital and operating costs on biochar and bioenergy systems could be significantly different between developing countries and developed regions. Financial benefits play a key role in the adoption of new technologies specifically in rural areas (Mohammadi et al., $2017 b$ ). Further research is also suggested to assess the lifecycle energy production and emissions mitigation of different combinations of biogas use and sludge processing lines for a region or a country. The local or national infrastructure as well as environmental aspects prioritised by decisionmakers determine possible uses of biogas and heat energy from AD-pyrolysis systems.

\section{Conclusions}

This study compares the environmental performances of three biogas pathways in different regions of the world using the same technologies and the same wastewater sludge as a feedstock. In all scenarios, digested sludge is pyrolyzed for the production of biochar to be mixed with forest soils. Scenario A, in which biogas is used as transportation fuel in Sweden, has significant environmental advantages over Scenario B (biogas for heat and electricity in the power sector in Brazil) and Scenario C (biogas for cooking in households in China). Pyrolysis gases, co-product of pyrolysis process, were captured with the motive of energy recovery. The heat from these gases in Scenario A was assumed to be used in households, substituting the current fuels used to produce district heating. The avoided use of district heating fuels played a dominant role in the reduction of most of the environmental impact, in this scenario. Scenario C exhibited the worst environmental performance where dewatering sludge and drying digested sludge were the critical processes. The source of electricity generation and the displaced fuel due to application of biogas and pyrolysis gases lead to significant difference in the LCA results of AD-pyrolysis systems in Sweden, Brazil and China. Overall, the integration of anaerobic digestion and pyrolysis as a novel energy-biochar production system could be a solution to enhance energy and nutrients recovery from pulp and paper mill sludge. However, to reduce the environmental impacts further, particularly in regions like China, the processes of sludge dewatering and drying need to be improved.

Data availability. The datasets used in this LCA are presented in Supplement.

Supplement. The supplement related to this article is available online at: https://doi.org/10.5194/adgeo-49-57-2019-supplement.

Author contributions. AM designed the model and the computational framework, analysed the data and developed the manuscript. GV contributed in writing and editing. MS, SE, KG discussed the results and commented on the manuscript.

Competing interests. The authors declare that they have no conflict of interest.

Special issue statement. This article is part of the special issue "European Geosciences Union General Assembly 2019, EGU Division Energy, Resources \& Environment (ERE)". It is a result of the EGU General Assembly 2019, Vienna, Austria, 7-12 April 2019.

Acknowledgements. This study was funded by a grant from the Swedish Agency for Economic and Regional Growth, grant number 20201239, project name FOSBE, and by a European Union grant through the Interreg Sweden-Norway program, grant number 20200023, project name IMTRIS.

Financial support. This research has been supported by a grant from the Swedish Agency for Economic and Regional Growth, grant number 20201239, project name FOSBE, and by a European Union grant through the Interreg Sweden-Norway program, grant number 20200023, project name IMTRIS.

Review statement. This paper was edited by Viktor Bruckman and reviewed by two anonymous referees. 


\section{References}

Al Seadi, T. and Lukerhurst, C.: Quality management of digestate from biogas plants used as fertilizer, Task 37 Energy from Biogas, IEA Bioenergy (2012), available at: http://www.iea-biogas.net/files/daten-redaktion/download/ publi-task37/digestate_quality_web_new.pdf (last access: 26 April 2019), 2012.

Ang, B. W. and Su, B.: Carbon emission intensity in electricity production: A global analysis, Energ. Policy, 94, 56-63, https://doi.org/10.1016/j.enpol.2016.03.038, 2016.

BigChar: Big Char CCT, available at: https://www.pyrocal.com.au/ (last access: 17 May 2019), 2015.

Börjesson, P. and Berglund, M.: Environmental systems analysis of biogas systems - Part I: Fuelcycle emissions, Biomass Bioenerg., 30, 469-485, https://doi.org/10.1016/j.biombioe.2005.11.014, 2006.

Brassard, P., Godbout, S., Pelletier, F., Raghavan, V., and Palacios, J. H.: Pyrolysis of switchgrass in an auger reactor for biochar production: A greenhouse gas and energy impacts assessment, Biomass Bioenerg., 116, 99-105, https://doi.org/10.1016/j.biombioe.2018.06.007, 2018.

Cao, Y. and Pawłowski, A.: Sewage sludge-to-energy approaches based on anaerobic digestion and pyrolysis: Brief overview and energy efficiency assessment, Renew. Sust. Energ. Rev., 16, 1657-1665, https://doi.org/10.1016/j.rser.2011.12.014, 2012.

Chen, S. and Chen, B.: Net energy production and emissions mitigation of domestic wastewater treatment system: A comparison of different biogas-sludge use alternatives, Bioresource Technol., 144, 296-303, https://doi.org/10.1016/j.biortech.2013.06.128, 2013.

Chen, Y., Yang, G., Sweeney, S., and Feng, Y.: Household biogas use in rural China: A study of opportunities and constraints, Renew. Sust. Energ. Rev., 14, 545-549, https://doi.org/10.1016/j.rser.2009.07.019, 2010.

Coimbra-Araújo, C. H., Mariane, L., Júnior, C. B., Frigo, E. P., Frigo, M. S., Araújo, I. R. C., and Alves, H. J.: Brazilian case study for biogas energy: Production of electric power, heat and automotive energy in condominiums of agroenergy, Renew. Sust. Energ. Rev., 40, 826-839, https://doi.org/10.1016/j.rser.2014.07.024, 2014.

Colzi Lopes, A., Valente, A., Iribarren, D., and GonzálezFernández, C.: Energy balance and life cycle assessment of a microalgae-based wastewater treatment plant: A focus on alternative biogas uses, Bioresource Technol., 270, 138-146, https://doi.org/10.1016/j.biortech.2018.09.005, 2018.

Devi, P. and Saroha, A. K.: Risk analysis of pyrolyzed biochar made from paper mill effluent treatment plant sludge for bioavailability and eco-toxicity of heavy metals, Bioresource Technol., 162, 308-315, https://doi.org/10.1016/j.biortech.2014.03.093, 2014.

Eskandari, S., Mohammadi, A., Sandberg, M., Eckstein, R. L., Hedberg, K., and Granström, K.: Hydrochar-Amended Substrates for Production of Containerized Pine Tree Seedlings under Different Fertilization Regimes, Agronomy, 9, 350, https://doi.org/10.3390/agronomy9070350, 2019.

European-Commission: European reference life cycle database (ELCD core database), version 3.2, Joint Research Centre (JRC) of the European Commission, http://eplca.jrc.ec.europa. eu/ELCD3/datasetDownload.xhtml (last access: 10 May 2019), 2014.
Granström, K.: Resource recovery from pulp and paper mills by adaptation of their wastewater treatment to biogas production, 19th European Biosolids \& Organic Resources Conference and Exhibition, 17-19 November 2014, Manchester, UK, 2014.

Granström, K., Sandberg, M., Hagelqvist, A., Nilsson, L., Arvsell, K., Samson-Akpan, E., Gustafsson, J., and Sonnö, R.: Energieffektiv avloppsrening med biogasproduktion samt kemikalieåtervinning från pappers- och massabruk (translation: Efficient forest industry wastewater treatment recovering energy and chemicals), Värmeforsk report no 1263, Stockholm, 2014.

Heimersson, S., Harder, R., Peters, G. M., and Svanström, M.: Including Pathogen Risk in Life Cycle Assessment of Wastewater Management. 2. Quantitative Comparison of Pathogen Risk to Other Impacts on Human Health, Environ. Sci. Technol., 48, 9446-9453, https://doi.org/10.1021/es501481m, 2014.

Hong, J., Hong, J., Otaki, M., and Jolliet, O.: Environmental and economic life cycle assessment for sewage sludge treatment processes in Japan, Waste Manage., 29, 696-703, https://doi.org/10.1016/j.wasman.2008.03.026, 2009.

Huang, M., Yang, L., Qin, H., Jiang, L., and Zou, Y.: Quantifying the effect of biochar amendment on soil quality and crop productivity in Chinese rice paddies, Field Crop. Res., 154, 172-177, https://doi.org/10.1016/j.fcr.2013.08.010, 2013.

Inventories, S. C. f. L. C.: Swiss Centre for Life Cycle Inventories, Ecoinvent Database v.3.1, available at: http://www.ecoinvent. org/ (last access: 15 May 2019), 2014.

Jacobson, S. and Pettersson, F.: An assessment of different fertilization regimes in three boreal coniferous stands, Silva Fenn., 44, 815-827, 2010.

Ji, C., Cheng, K., Nayak, D., and Pan, G.: Environmental and economic assessment of crop residue competitive utilization for biochar, briquette fuel and combined heat and power generation, J. Clean. Prod., 192, 916-923, https://doi.org/10.1016/j.jclepro.2018.05.026, 2018.

Lehmann, J. and Joseph, S.: Biochar for Environmental Management: Science, Technology and Implementation, Earthscan, London, 1-12, 2015.

Li, H. and Feng, K.: Life cycle assessment of the environmental impacts and energy efficiency of an integration of sludge anaerobic digestion and pyrolysis, J. Clean. Prod. 195, 476-485, https://doi.org/10.1016/j.jclepro.2018.05.259, 2018.

Li, Y., Hu, S., Chen, J., Müller, K., Li, Y., Fu, W., Lin, Z., and Wang, H.: Effects of biochar application in forest ecosystems on soil properties and greenhouse gas emissions: a review, J. Soil. Sediment., 18, 546-563, https://doi.org/10.1007/s11368-017-1906-y, 2018.

Lu, T., Yuan, H., Wang, Y., Huang, H., and Chen, Y.: Characteristic of heavy metals in biochar derived from sewage sludge, J. Mater. Cycles Waste, 18, 725-733, https://doi.org/10.1007/s10163-0150366-y, 2016.

Mohammadi, A., Cowie, A., Anh Mai, T. L., Anaya de la Rosa, R., Kristiansen, P., Brandão, M., and Joseph, S.: Biochar use for climate-change mitigation in rice cropping systems, J. Clean. Prod., 116, 61-70, https://doi.org/10.1016/j.jclepro.2015.12.083, 2016 a.

Mohammadi, A., Cowie, A., Anh Mai, T. L., Anaya de la Rosa, R., Kristiansen, P., Brandão, M., and Joseph, S.: Quantifying the greenhouse gas reduction benefits of utilising straw biochar and enriched biochar, Enrgy. Proced., 97, 254-261, 2016 b. 
Mohammadi, A., Cowie, A. L., Anh Mai, T. L., Brandão, M., Anaya de la Rosa, R., Kristiansen, P., and Joseph, S.: Climate-change and health effects of using rice husk for biochar-compost: Comparing three pyrolysis systems, J. Clean. Prod., 162, 260-272, $2017 \mathrm{a}$.

Mohammadi, A., Cowie, A. L., Cacho, O., Kristiansen, P., Anh Mai, T. L., and Joseph, S.: Biochar addition in rice farming systems: Economic and energy benefits, Energy, 140, 415-425, https://doi.org/10.1016/j.energy.2017.08.116, 2017 b.

Mohammadi, A., Sandberg, M., Venkatesh, G., Eskandari, S., Dalgaard, T., Joseph S., and Granström, K.: Environmental analysis of producing biochar and energy recovery from pulp and paper mill biosludge, J. Ind. Ecol., https://doi.org/10.1111/jiec.12838, online first, 2019a.

Mohammadi, A., Sandberg, M., Venkatesh, G., Eskandari, S., Dalgaard, T., Joseph, S., and Granström, K.: Environmental performance of end-of-life handling alternatives for paper-and-pulpmill sludge: Using digestate as a source of energy or for biochar production, Energy, 182, 594-605, $2019 \mathrm{~b}$.

Mohammadi, A., Sandberg, M., Venkatesh, G., Eskandari, S., and Granström, K.: Anaerobic digestion of pulp and paper mill sludge: life cycle assessment of alternative uses of biogas, Geophys. Res. Abstr., EGU2019-18034, EGU General Assembly 2019, Vienna, Austria, 2019c.

Paz-Ferreiro, J., Gascó, G., Gutiérrez, B., and Méndez, A.: Soil biochemical activities and the geometric mean of enzyme activities after application of sewage sludge and sewage sludge biochar to soil, Biol Fert. Soils, 48, 511-517, https://doi.org/10.1007/s00374-011-0644-3, 2012.

Persson, M., Jönsson, O., and Wellinger, A.: Biogas Upgrading to Vehicle FuelStandards and Grid Injection, IEA Bioenergy, Task 37 - Energy from Biogas and Landfill Gas, available at: http://task37.ieabioenergy.com/files/daten-redaktion/download/ publi-task37/upgrading_report_final.pdf (last access: 2 May 2019), 2006.

Pöschl, M., Ward, S., and Owende, P.: Evaluation of energy efficiency of various biogas production and utilization pathways, Appl. Energ., 87, 3305-3321, https://doi.org/10.1016/j.apenergy.2010.05.011, 2010.
PRè Consultants: SimaPro 8.0.4, Environmental Database, Amersfoort, the Netherlands, 2014.

Silva, M. I., Mackowiak, C., Minogue, P., Reis, A. F., and Moline, E. F. d. V.: Potential impacts of using sewage sludge biochar on the growth of plant forest seedlings, Ciência Rural, 47, 1, https://doi.org/10.1590/0103-8478cr20160064, 2017.

Sparrevik, M., Field, J. L., Martinsen, V., Breedveld, G. D., and Cornelissen, G.: Life cycle assessment to evaluate the environmental impact of biochar implementation in conservation agriculture in Zambia, Environ. Sci. Technol., 47, 1206-1215, https://doi.org/10.1021/es302720k, 2013.

Starr, K., Gabarrell, X., Villalba, G., Talens, L., and Lombardi, L.: Life cycle assessment of biogas upgrading technologies, Waste Manage., 32, 991-999, https://doi.org/10.1016/j.wasman.2011.12.016, 2012.

Suh, Y.-J. and Rousseaux, P.: An LCA of alternative wastewater sludge treatment scenarios, Resources, Conservation and Recycling, 35, 191-200, https://doi.org/10.1016/S09213449(01)00120-3, 2002.

Ulery, A. L., Graham, R. C., and Amrhein, C.: Wood-Ash composition and soil $\mathrm{pH}$ following intense burning, Soil Sci., 156, 358-364, 1993.

Vadeboncoeur, M. A., Hamburg, S. P., Yanai, R. D., and Blum, J. D.: Rates of sustainable forest harvest depend on rotation length and weathering of soil minerals, Forest Ecol. Manage., 318, 194205, https://doi.org/10.1016/j.foreco.2014.01.012, 2014.

Van Zwieten, L., Kimber, S., Morris, S., Chan, K. Y., Downie, A., Rust, J., Joseph, S., and Cowie, A.: Effects of biochar from slow pyrolysis of papermill waste on agronomic performance and soil fertility, Plant Soil, 327, 235-246, https://doi.org/10.1007/s11104-009-0050-x, 2010.

Venkatesh, G.: Recovery of different types of resources from wastewater - A structured review, Vatten, 74, 1-18, 2018. 